\title{
THE EFFECTS OF ASPIRIN ON APOPTOSIS OF NEUTROPHIL GRANULOCYTES
}

\author{
VASILEV S*, MAJSTOROVIĆ IVANA*, GAŠIĆ SONJA*, VUČEVIĆ DRAGANA*, VASILIJIĆ S*, \\ ĆUPIĆ $\mathrm{V}^{* *}$ and ČOLIĆ $\mathrm{M}^{*}$ \\ *Military Medical Academy, Institute for Medical Research, Belgrade; \\ ${ }^{* *}$ Faculty of Veterinary Medicine, Belgrade \\ (Received 15. March 2006)
}

Neutrophils are a part of the immune system, and they are involved in host defence against microorganisms. Neutrophil granulocytes have the shortest lifespan among leukocytes, which can be modulated by cytokines and pharmacological agents. The effect of aspirin on apoptosis of inflammatory granulocytes has not been studied in detail yet, and therefore was the chosen subject of this study. Inflammatory granulocytes have been isolated from polyvinyl sponges implanted under the skin of Albino Oxford (AO) rats. Inflammatory cells that were isolated 20 hours later were more than $95 \%$ neutrophil granulocytes. The cells were cultivated $24 \mathrm{~h}$ with different concentrations of aspirin ranging from $1 \mu \mathrm{M}$ to $10 \mathrm{mM}$. After the cultivation period, apoptosis of neutrophils was assesed by morphological criteria, as well as by flow cytometry (after staining the cells with propidium iodide). We found that at concentrations from $0,1 \mathrm{mM}$ to 2,5 mM aspirin inhibited apoptosis of granulocytes, but at $10 \mathrm{mM}$ aspirin induced apoptosis of these cells.

Key words: aspirin, neutrophil granulocytes, apoptosis

\section{INTRODUCTION}

Aspirin is a widely used antiinflammatory agent primarily because it is effective in the relief of pain and inflammation (Vane et al., 1998; Awtry and Loscalzo, 2000; Hinz and Brune, 2002). Recently, aspirin and some other nonsteroidal antiinflammatory drugs (NSAIDs) received particular attention because of their protective effects against colon cancer (Thun, 1997; Porter et al., 2000) and beneficial effects in cardiovascular diseases (Tegeder et al., 2001).

Neutrophils are a part of the immune system, and they are involved in host defence against microorganisms. Neutrophils are the first leukocytes to migrate to the inflammation site, hours before other cells do so (Witko-Sarsat et al., 2000; Girard, 2003). Neutrophil granulocytes have the shortest lifespan among leukocytes (12-48 h). Their lifespan can be modulated by cytokines, pharmacological agents and xenobiotics (Girard, 2003; Maianski et al., 2004). 
Apoptosis is a gene-directed mechanism for the elimination of unnecessary or unwanted cells from the organism. Apoptosis plays an important role in development, in tissue homeostasis and in the defence against viral infections and mutations. This process is regulated by complex molecular signaling systems (Kam and Ferch, 2000; Dlamini et al., 2004; Guimaraes and Linden, 2004). Aspirin and other NSAID induce apoptosis in several cell types (human colorectal tumor cell lines, fibroblasts, B-cell chronic lymphocytic leukaemia cells, myeloid leukaemia cell lines and colon cancer cells in vivo) (Pique et al., 2000). Apoptosis of neutrophil granulocytes is important for the resolution of inflammation (Kam and Ferch, 2000), since failure to undergo this form of cell death leads to increased tissue damage and exacerbation of the inflammatory response. It is of interest to prolong the lifespan of granulocytes in acute inflammation. Manipulation of the rate of apoptosis in inflammatory effector cells (neutrophils, eosinophils, monocytes and macrophages) could be of therapeutic benefit.

In the present study, we examined the effects of aspirin on the apoptosis of the rat inflammatory neutrophil granulocytes.

\section{MATERIALS AND METHODS}

\section{Animals}

Male 10 weeks old Albino Oxford (AO) rats, weighing 200-220 g, bred at the Institute for Medical Research, Military Medical Academy (MMA), Belgrade, were used in the experiment. The rats were fed standard laboratory chow (Veterinarski zavod Subotica) and tap water ad libitum. All experimental procedures on animals were conducted in adherence to the $\mathrm{NIH}$ guidelines for the use of experimental animals, with the approval of the MMA Ethical Committee.

\section{Neutrophil collection}

Effects of aspirin on the apoptosis of inflammatory neutrophil granulocytes was studied using a model of inflammation by implanting sterile polyvinyl sponges under the skin of rats (Middleton and Campebell, 1989). Rats were anaesthetized with ether (Merck) and their skin on the back was shaved and swabbed with $70 \%$ ethanol. Small incisions were made in the skin and pockets under the skin were made by using the tip of the scissors. Sterile polyvinyl sponge pieces $(2 \times 1,5 \times 0,5 \mathrm{~cm})$ were soaked in physiological saline, and two sponges per rat were implanted subcutaneously and pushed down under the skin. After 20 hours, the rats were sacrificed by inhalation anaesthesia and the sponges were retrieved aseptically. Infiltrating cells from the sponges were collected using RPMI 1640 medium containing $2 \%$ heat-inactivated fetal calf serum (FCS) (ICN Pharmaceuticals, Costa Mesa, USA), penicillin (50 IU/ml) and streptomycin $(50 \mu \mathrm{g} / \mathrm{ml})$, and RPMI 1640 medium with $0.04 \%$ EDTA. Cells were washed, resuspended, filtered through a nylon mesh, washed once more for 10 minutes and finally resuspended in complete RPMI 1640 medium containing 10\% FCS. Cells were diluted in Trypan Blue and counted in a standard hematocytometer chamber. Isolated inflammatory cells were more than 95\% neutrophil granulocytes. Viability of neutrophils was higher than $98 \%$. 


\section{Cultivation of neutrophil granulocytes}

Neutrophil granulocytes were plated in 96 -well plates $\left(5 \times 10^{5}\right.$ cells/well, $200 \mu \mathrm{l}$ ) along with increasing concentrations $(0.01-10 \mathrm{mM}$ ) of aspirin (Sigma Chemical $\mathrm{Co}$ ) and cultivated for $24 \mathrm{~h}$. The control consisted of cells cultivated in complete RPMI 1640 medium. Culture supernatants were collected after $24 \mathrm{~h}$ and used for the measurement of nitric oxide (NO). The cells were used for the detection of apoptosis.

\section{Measurement of apoptosis}

For the measurement of apoptosis, two different methods were used. Morphological analysis using morphological criteria (chromatin condensation, nuclear pyknosis or nuclear fragmentation) was performed after fixation and staining of the cells with Türk reagent using light microscopy as previously originally described for lymphocytes (Čolić et al., 2000). Apoptosis was also detected by staining hypodiploid nuclei using propidium iodide (PI) (Migita et al., 1994; Vermes et al., 2000). After incubation, neutrophils were washed once with phosphate buffered saline (PBS) and resuspended in $0,4 \mathrm{ml}$ solution with $20 \mu \mathrm{l}$ of $\mathrm{PI}(1 \mu \mathrm{g} / \mathrm{ml})$. The analysis was performed on an EPICS XL-MLC cytofluorometer (Coulter, Germany).

\section{Measurement of NO production}

Production of $\mathrm{NO}$, quantified by the accumulation of nitrite in the $24 \mathrm{~h}$ culture medium, was measured spectrophotometrically using the Griess reaction with sodium nitrite as a standard (Green et al., 1982). Culture supernatants $(50 \mu l)$ were mixed with equal volumes of $1 \%$ sulphanilamide (Sigma Chemicals Co., St Louis, Mo., USA) in $5 \% \mathrm{H}_{3} \mathrm{PO}_{4}$ and $0.1 \% \mathrm{~N}$-1-naphthylethylene diamine dihydrochloride (Sigma Chemicals Co., St Louis, Mo., USA) in distilled water, and after 10 minutes at room temperature the absorbance, was measured at $570 \mathrm{~nm}$.

\section{Statistical analysis}

All data are expressed as mean \pm standard deviation. Each test was performed at least three times. Statistical analysis was performed by Student's ttest, using the PC Program. A p value less than 0.05 was considered significant.

\section{RESULTS}

\section{Effect of aspirin on apoptosis of rat neutrophil granulocytes}

After a 24-hour incubation of neutrophils isolated from sponges with different concentrations of aspirin at $37^{\circ} \mathrm{C}$, apoptosis was determined by the morphological method. It was found that aspirin, at concentrations from $100 \mu \mathrm{M}$ to 2,5 mM, significantly inhibited the spontaneous apoptosis of these cells. However, concentration of $10 \mathrm{mM}$ of the drug promoted apoptosis of granulocytes (Figure 1). Similar results were confirmed by using flow cytometry after staining the cells with PI (Figure 2). Morphology of freshly isolated neutrophils is shown in Figure 
3a. The appearance of viable and spontaneously apoptotic neutrophils in the culture is presented in Figure $3 \mathrm{~b}$. Figure $3 \mathrm{c}$ shows that most neutrophils incubated for 24 hours with $10 \mathrm{mM}$ aspirin showed features of apoptosis such as condensed and/or fragmented nuclei.

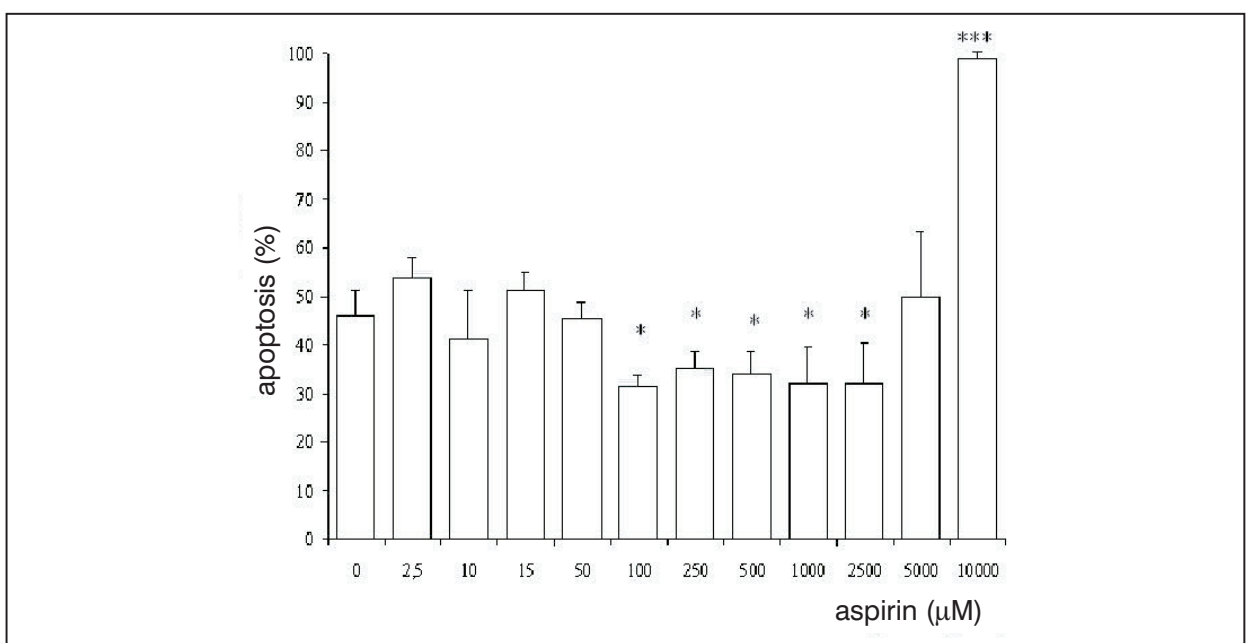

Figure 1. The effect of aspirin on apoptosis of neutrophil granulocytes in culture. Apoptosis was measured after staining the cells with Türk reagent and analysis by light microscopy, using morphological criteria as described in Materials and Methods. Values are given as mean \pm SD of triplicates from one representative experiment, out of several ones with similar results. Results of morphological analysis are given on the basis of 500 counted cells in each native preparation $\left({ }^{*} p<0.05 ;{ }^{* * *} p<0.001\right.$ compared to control)

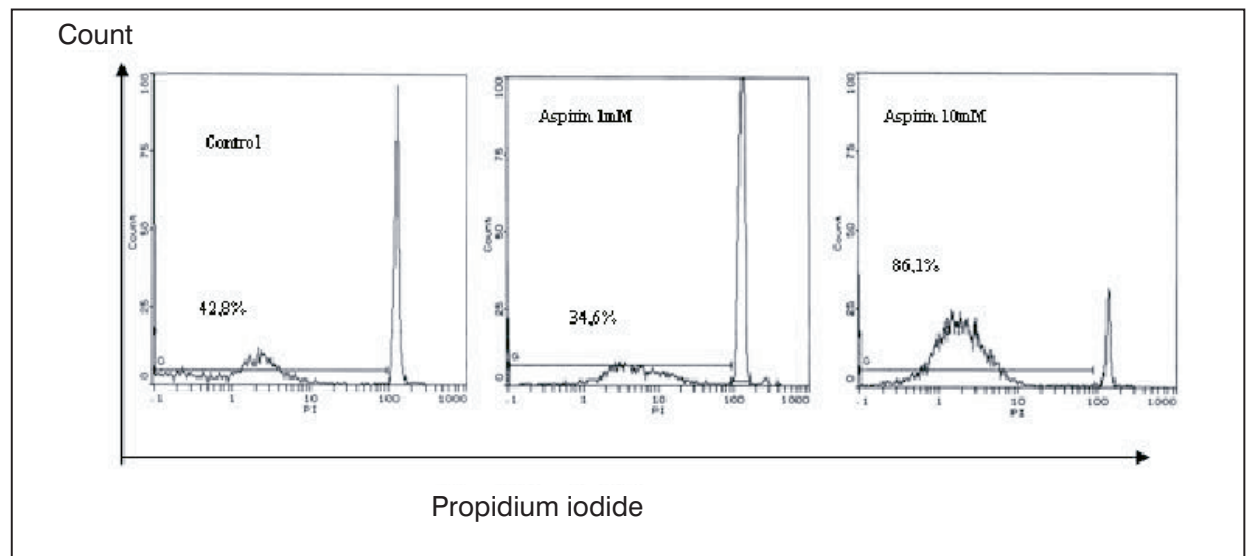

Figure 2. The effect of aspirin on apoptosis of neutrophil granulocytes in culture. Apoptosis was measured after staining the cells with propidium iodide using cytofluorometry as described in Materials and Methods. The number above the horizontal line shows the percentage of hypodiploid nuclei 

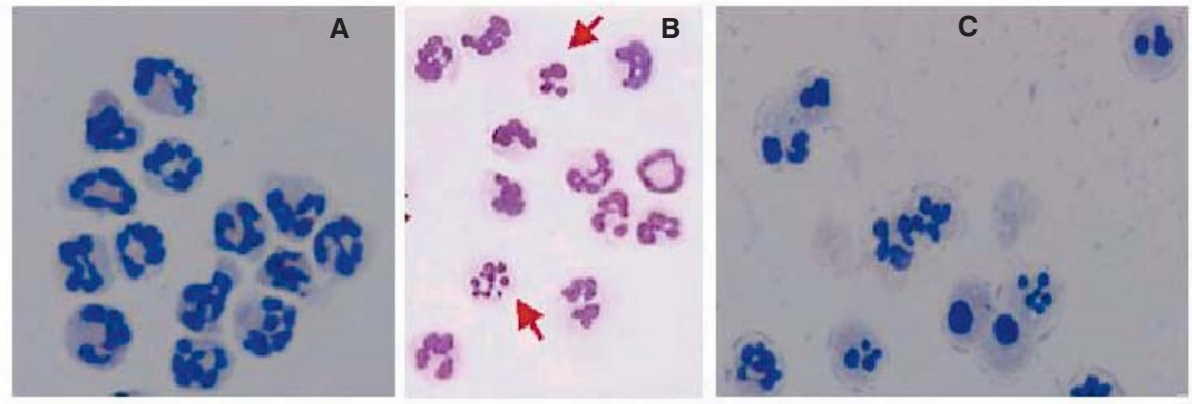

Figure 3. Cytospin preparations of neutrophil granulocytes, stained by May GrünwaldGiemsa. Freshly isolated neutrophils (A); After 24h incubation (B). Fig 3C shows the appearance of neutrophils incubated with $10 \mathrm{mM}$ of aspirin for $24 \mathrm{~h}$

\section{Effect of aspirin on NO production}

It is known that NO, depending on the concentration, suppresses or promotes apoptosis. Therefore, in subsequent experiments, we investigated the effect of different concentrations of aspirin on NO production by inflammatory granulocytes. We found that aspirin at concentrations from 0,0025 to $5 \mathrm{mM}$, failed to produce any significant effect on the baseline production of NO (as assessed by the quantity of nitrite measured by the Griess reaction) by neutrophil granulocytes cultured for 24 hours. However, at the concentration of $10 \mathrm{mM}$, aspirin caused a statistically significant decrease in NO production by these cells (Figure 4).

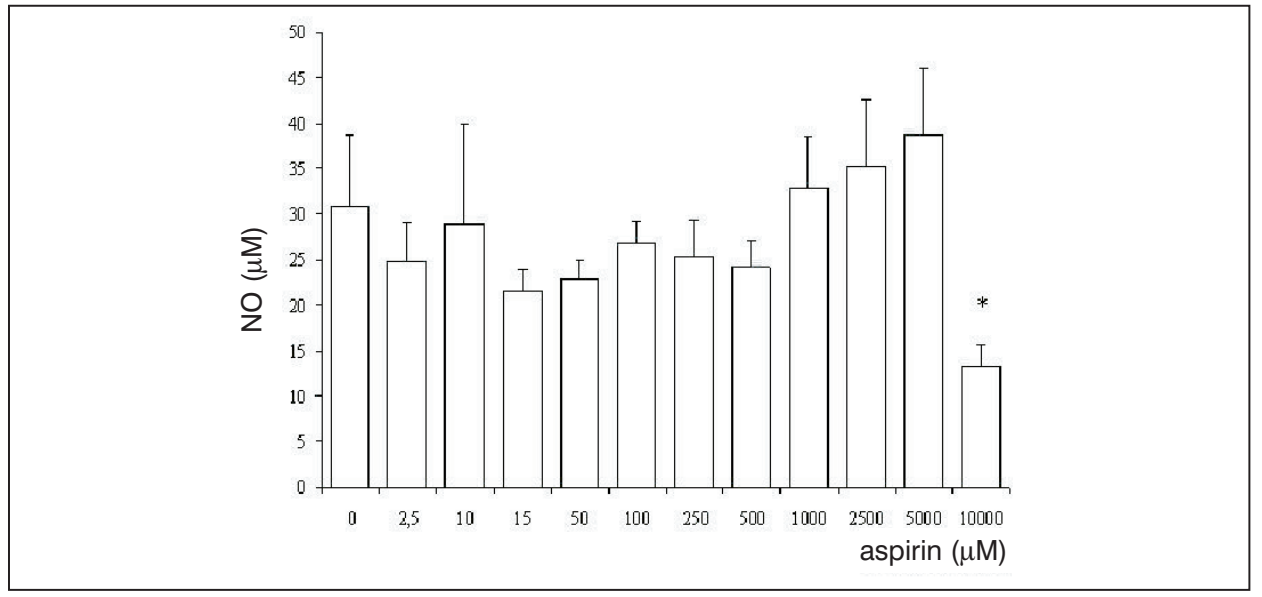

Figure 4. The effect of aspirin on the production of nitric oxide by neutrophil granulocytes in $24 \mathrm{~h}$ culture. Production of nitric oxide was measured spectrophotometrically using the Griess method as described in Materials and Methods. Values are given as mean \pm SD of triplicates from one representative experiment, out of several ones with similar results $\left({ }^{*} p<0.05\right.$ compared to control) 


\section{DISCUSSION}

In our experiment, we found that aspirin, in concentrations from 2.5 to $50 \mu \mathrm{M}$, did not affect, with any statistical significance, the degree of spontaneous apoptosis of rat neutrophil granulocytes after 24 hours of incubation at $37{ }^{\circ} \mathrm{C}$. When incubated with neutrophils in concentrations ranging from 100 to $2500 \mu \mathrm{M}$, aspirin significantly inhibited the spontaneous apoptosis of these cells. The relative numbers of apoptotic cells have fallen from $45 \%$, which has been the level of spontaneous apoptosis, to 37.9 and $30.0 \%$ with aspirin. However, when incubated with a high aspirin concentration of $10 \mathrm{mM}$, neutrophils were induced towards apoptosis. Namely, their spontaneous apoptosis of $45 \%$ increased to $85-$ $100 \%$.

Similar results have not yet been published. There are very few works about the effect of aspirin on the apoptosis of neutrophil granulocytes. Garcia-Martinez et al. (2003) have found that, after an incubation of 24 hours, aspirin, in the concentration of $10 \mathrm{mM}$, induces apoptosis of human neutrophils (in peripheral circulation), while in the concentration of $75 \mu \mathrm{M}$ it does not modulate this process. Galichs et al. (2004) have determined that the apoptosis of neutrophils from peripheral blood of patients taking aspirin as their antiaggregation therapy, after 24 hours in culture, equals that of the controls. However, in patients suffering from acute coronary syndrome, neutrophil apoptosis was reduced. Sera of these patients inhibited apoptosis of neutrophils from healthy donors, due to the presence of TNF $\alpha$, GM-CSF and IL-1 $\beta$.

There are numerous publications regarding the pro- and anti-apoptotic effect of aspirin on different cell types. When Ricci et al., (2003) incubated caco-2 cells (a human colon adenocarcinoma cell line) with 2 and $5 \mathrm{mM}$ of aspirin, they found that it caused apoptosis. Also, aspirin, in concentrations of 1 and 2,5 mM, induces a statistically significant degree of apoptosis in three different cell lines of human colon cancer, after an incubation lasting 48 or 72 hours (Goel et al., 2003). In the concentration of $10 \mathrm{mM}$, aspirin induces apoptosis after 12 hours of incubation in Jurkat and Molt-4 cells (acute T cell leukaemia lines), as well as Raji cells (a Burkitt B cell lymphoma line) (Pique et al., 2000).

The finding that aspirin, in concentrations up to $100 \mu \mathrm{M}$, does not affect neutrophil apoptosis, while at $10 \mathrm{mM}$ it induces apoptosis, is in concurrence with other studies describing the effects of aspirin on neutrophils. Our data agree well with the pro- and anti-apoptotic effects of aspirin on other cells.

Neutrophils are highly specialized white blood cells that participate in the host defense against infection (Simon, 2003). These cells are the first line of defense of the innate immune system. Neutrophils are especially important when fighting microorganisms (bacteria and certain fungi) by phagocytosis and releasing toxic mediators. They have a short half-life if they are not recruited to the site of inflammation. Inflammatory mediators, cytokines, growth factors and chemical mediators mediate duration of their life-span (Ward et al., 1999, Simon, 2003). However, neutrophils are terminally differentiated cells and, therefore, because of their short life-span it is difficult to study neutrophils from the blood in vitro (Simon, 2003). Nevertheless, neutrophils life span changes as they 
transmigrate from blood to inflammatory tissue. These changes can be examined ex vivo and in vitro, where these inflammatory cells live longer. It is easy to obtain such a cell population from the blood, as well as from subcutaneously implanted sponges.

The tight regulation that governs neutrophils behavior is necessary because the content of neutrophil granules can be noxious to the host tissue (Ćupić, 1997). In the resolution of inflammation, the accumulated neutrophils need to be safely removed. Apoptosis plays an important role in eliminating such neutrophils from inflammed tissues. Most studies have been performed on purified blood neutrophils aiming to understand the molecular events that control apoptosis in these cells (Simon, 2003). Apoptosis is the physiologic cell death of neutrophils. The number of neutrophils is regulated in vivo by their production in the bone marrow and by apoptosis. Apoptosis at the inflammatory site appears to be delayed when survival factors are generated by pro-inflammatory cytokines (Akgul et al., 2001).

Nitric oxide (NO) is the key mediator in a great number of physiological and pathophysiological processes. It can regulate the rate of apoptosis in many cell types including human inflammatory cells. NO has both pro and antiapoptotic properties depending largely on the concentration and flux of NO and cell type. Low concentrations of NO (less than $100 \mu \mathrm{M}$ ) (Bogdan et al., 2000) usually have protective effects on cells, whereas higher concentrations derived from inducible isoform of NO synthase drive the cell to death (Taylor et al., 2003). NO is able both to promote and delay inflammatory cell apoptosis and the mechanisms are still not fully elucidated. Because of the importance of $\mathrm{NO}$ in apoptosis of neutrophils we examined its concentration in culture. In our experiments, aspirin decreased the quantity of NO in neutrophil culture supernatants, when incubated with these cells in a concentration of $10 \mathrm{mM}$, only. It is possible that this observation is related to the induction of apoptosis by aspirin in this concentration.

Based on the results of our work, the following may be concluded: aspirin has a dichotomal effect on the apoptosis of rat inflammatory neutrophils. Namely, in concentrations of $100-2500 \mu \mathrm{M}$, aspirin inhibits apoptosis, but in the concentration of $10 \mathrm{mM}$, it has the opposite effect, i.e. induces apoptosis. The fact that aspirin, in concentrations that lie within the range of therapeutic plasma levels, causes inhibition of neutrophil apoptosis is a very important finding that may contribute to our knowledge of mechanisms of aspirin-induced damage to the mucosa of the stomach and intestine.

Address for correspondence:

Professor Vitomir Cupić

Department of Pharmacology and Toxicology,

Faculty of Veterinary Medicine,

Belgrade, Serbia

E-mail: vcupic@vet.bg.ac.yu 


\section{REFERENCES}

1. Akgul C, Moulding DA, Edwards SWI, 2001, Molecular control of neutrophil apoptosis, FEBS letters, 487, 318-22

2. Awtry EH, Loscalzo J, 2000, Aspirin. Circulation, 101, 1206-18

3. Bogdan C, Röllinghoff M,Diefenbach A. 2000, Reactive oxygen and reactive nitrogen intermediates in innate and specific immunity, Curr Opin Immunol, 12, 64-76.

4. Čolić M, Gasić S, Vučević D, Pavicic L, Popovic P, Jandric D, et al., 2000, Modulatory effect of 7-thia8-oxoguanosine on proliferation of rat thymocytes in vitro stimulated with Concanavalin $\mathrm{A}$, Int $\mathrm{J}$ Immunopharmacol, 22, 203-12.

5. Ćupić V, 1997, Nesteroidna antiinflamatorna sredstva. Plenarno predavanje po pozivu. Zbornik radova sa 10 savetovanja veterinara Srbije. Zlatibor, 16-20. septembar.

6. Dlamini Z, Mbita Z, Zungu M, 2004, Genealogy, expresion, and molecular mechanisms in apoptosis, Pharmacol Therap, 101, 1-15

7. Garlichs CD, Eskafi S, Cicha I, Schmeisser A, Walzog B, Raaz D, et al. 2004, Delay of neutrophil apoptosis in acute coronary syndromes, J Leuk Biol, 75, 5, 8 28-35

8. Garcia-Martinez JM, Fresno Vara JA, Lastres P, Bernabeu C, Betes PO, Martin-Perez J, 2003, Effect of metamizol on promyelocytic and terminaly diferentiated granulocytic cells: comparative analysis with acetylsalicylic acid and diclofenac, Biochem Pharmacol, 65, 209-17.

9. Girard D, 2003, Activation of human polymorphonuclear neutrophils by environmental contaminants, Rev Environ Health, 18, 2, 77-93

10. Goel A, Chang DK, Ricciardiello L, Gasche C, Boland CR, 2003, A novel mechanism for aspirinmediated growth inhibition of human colon cancer cells, Clin Canc Res, 9, 383-90.

11. Green LC, Wagner DA, Glogowski J, Skipper PL, Wishnok JS, Tannenbaum SR, 1982, Analysis of nitrate, nitrite and $\left({ }^{15} \mathrm{~N}\right)$ nitrate in biological fluids, Anal biochem, 126, 131-8.

12. Guimaraes CA, Linden R, 2004, Programed cell death, Eur J Biochem, 271, 1638-50.

13. Hinz B, Brune K, 2002, Cyclooxigenase-2 - 10 years later, J Pharmacol Exp Therap. 300, 367-75.

14. Kam PCA,Ferch NI, 2000, Apoptosis: mechanisms and clinical implications, Anaesthesia, 55, 108193.

15. Maianski NA, Maianski AN, Kuijpers TW, Roos D, 2004, Apoptosis of neutrophils, Acta Haematol, 111, 56-66.

16. Middleton MM, Campbell PA, 1989, Functions of purified mouse neutrophils isolated from gelatin sponges, J Leuk Biol, 46, 461-6.

17. Migita K, Eguchi K, Kawabe Y, Mizokami A, Tsukada T, Nagataki S, 1994, Prevention of anti-CD3 monoclonal antibody-induced thymic apoptosis by protein tyrosine kinase inhibitors. J Immunol,153, 8, 3457-65.

18. Pique M, Barragan M, Dalmau M, Bellosillo B, Pons G, Gil J, 2000, Aspirin induces apoptosis through mitochondrial cytohrome c release, FEBS Letters, 480, 193-6.

19. Porter SN, Howarth GS, Butler RN, 2000, Non-steroidal anti-inflammatory grugs and apoptosis in the gastrointestinal tract: potential role of the pentose phosphate pathways, Eur J Pharmacol, 397, 1-9.

20. Ricchi P, Palma AD, Matola TD, Apicella A, Fortunato R, Zarrilli R, et al, 2003, Aspirin protects caco-2 cells from apoptosis after serum deprivation through the activation of a phosphatidylinositol 3 kinase / AKT/p21/Cip/waf1 pathway, Mol Pharmacol, 64, 407-14.

21. Simon $H U, 2003$, Neutrophil apoptosis pathway and their modifications in inflammation, Immunol Rev, 193,101-10.

22. Taylor EL, Megson IL, Haslett C, Rossi AG: 2003, Nitric oxide: a key regulator of myeloid inflammatory cell Apoptosis, Cell death differen, 10, 418-30.

23. Tegeder I, Pfeilschifter J,Geisslinger G, 2001, Cyclooxygenase-independent actions of cxclooxygenase inhibitors, FASEB J, 15, 2057-72.

24. Thun MJ, 1997, Aspirin and gastrointestinal cancer, Adv Exp Med Biol, 400A, 395-402.

25. Vane JR, Bakhle YS, Botting RM, 1998, Cyclooxigenases 1 and 2, Ann Rev Pharmacol Toxicol, 38, 97-120. 
26. Ward C, Dransfield I, Chilvers ER, Haslett C, Rossi AG, 1999, Pharmacological manipulation of granulocyte apoptosis: potential therapeutic targets, TIPS, 20, 503-9.

27. Vermes I, Haanen C, Reutelingsperger C, 2000, Flow cytometry of apoptotic cell death, J Immunol Meth, 243,167-90.

28. Witko-Sarsat V, Rieu P, Descamps-Latscha B, Lesavre P, Halbwachs-Mecarelli L, 2000, Neutrophils: molecules, functions and pathophysiological aspects, Lab Invest, 80, 5, 617.

\title{
EFEKTI ASPIRINA NA APOPTOZU NEUTROFILNIH GRANULOCITA
}

\author{
VASILEV S, MAJSTOROVIĆ IVANA, GAŠIĆ SONJA, VUČEVIĆ DRAGANA, VASILIJIĆ S, \\ ĆUPIĆ V i ČOLIĆ M
}

\section{SADRŽAJ}

Neutrofilni granulociti su deo imunog sistema, uključenog u odbranu od mikroorganizama. Oni imaju najkraći životni vek među leukocitima, koji se može modulisati citokinima i farmakološkim agensima, a do sada nije ispitivan efekat aspirina na apoptozu inflamatornih granulocita. Zbog toga je u ovoj studiji ispitivan efekat aspirina na apoptozu inflamatornih neutrofilnih granulocita pacova. Inflamatorni granulociti su izolovani iz polivinilskih sunđera, potkožno implantiranih, pacovima Albino Oxford (AO) soja. Inflamatorne ćelije, izolovane 20 sati kasnije, najvećim delom (više od $95 \%$ ) predstavljaju neutrofilne granulocite. Ove ćelije su kultivisane 24 sata sa aspirinom u koncentracijama od $1 \mu \mathrm{M}$ do $10 \mathrm{mM}$. Posle ovog perioda, supernatanti su sakupljani i korišćeni za merenje koncentracije NO. Ćelije su bojene propidijum jodidom i apoptoza je analizirana na protočnom citofluorimetru, kao i pomoću morfoloških kriterijuma. Ustanovljeno je da u koncentracijama od 0,1 do 2,5 mM aspirin inhibira, a samo u visokim koncentracijama (10 mM) indukuje apoptozu ovih ćelija. Aspirinom indukovana apoptoza je bila u pozitivnoj korelaciji sa smanjenom produkcijom NO. 